\title{
Institutional and Business Cross-border Cooperation in the Textile and Clothing Industry
}

\author{
Flávio Nunes \\ Centre of Studies on Geography and Spatial Planning, \\ University of Minho, Portugal
}

\begin{abstract}
In the European context, two cross-border regions, the North (Portugal) and Galicia (Spain), play a major role in the textile and clothing industry, although with significant differences in the business strategies they follow. These differences are essentially related to the specialization of North Portugal in small and medium-sized production activities, in opposition to the specialization of large Galician companies in more valueadded activities, particularly in the retailing and marketing of their own brands. The goal of this study is to evaluate the results of both institutional and business cooperation efforts to bolster cross-border competitiveness in this sector of activity. Methodologically, a quantitative approach is employed, based on the statistical analysis of databases that characterize this business sector, as well as a qualitative approach, based on in-depth interviews, not only with business managers involved in crossborder production networks, but also with the sector's most representative institutional actors. The results suggest there is an ongoing cross-border clustering process, derived particularly from more intense institutional cooperation. This process requires greater maturity in terms of business relations, as they still seem to be restricted by some cultural barriers associated to the border effect.
\end{abstract}

Keywords: Textile and Clothing Industry; Business Cooperation; Institutional Networks; Cross-border Cluster; Economic Integration; Iberian Peninsula.

\section{INTRODUCTION}

This study intends to evaluate the economic integration process in two border regions in the particular case of the textile and clothing industry. In the current times of economic liberalization characterized by several challenges raised by the progressive integration of global markets $[17,19,20]$, this article intends to assess whether this industry competitiveness has been bolstered in the cross-border territory of Galicia in Spain and the North of Portugal, by the broadening of institutional and business cooperation.

Although the textile and clothing sector is important in the production structure of both regions in terms of number of companies, work posts, turnover and contribution to national exports, there are significant regional and specialization differences. Our goal is to reveal these differences in order to identify complementarities between Galicia and the North Portugal, as well as evaluate if those complementarities have been boosting a stronger and gainful cooperation between the main business and institutional actors on both sides of the border.

Agglomeration economies derived from the concentration of a large number of companies and institutional actors in geographically contiguous territories, despite being separated by a border, frequently provide opportunities for multiple business cooperation agreements, for joint innovation investments, as well as for the common use of specialized infrastructure and services [5, 14, 18, 26]. In fact, cross-border clusters have been emerging worldwide in different economic activities [4,9]. Also in the northwest part of the Iberian Peninsula the specific competences in each of its border regions, if adequately coordinated, may contribute to 
increase the economic competitiveness of the textile and clothing sector. Indeed, the complementarity of the value chains segments between Galicia and North Portugal in this economic activity, has already warranted significant public support, aimed at encouraging institutional cooperation projects and the emergence of a cross-border cluster in this territory $[6,10,11,22]$. Methodologically, we intend to evaluate the results of these institutional efforts, identifying the domains in which there has been greater cross-border institutional cooperation, based on a literature review and also on the analysis of the information collected from interviews with the sector's main representative associations. We also aim to evaluate the direction cross-border business relationships have taken, based on 65 in-depth interviews with private entrepreneurs located in this territory, so as to evaluate ongoing business interactions and their main motivations, as well as the main obstacles they have encountered in the pursuit of cross-border cooperation.

The article is organized into four sections. The first part characterizes the textile and clothing industry in the Galicia-North Portugal Euroregion and its complementarities, based on the literature review and on the statistical analysis of businesses databases. The second and third part evaluates the tendencies of an interregional clustering process, by exploring the institutional and business cooperation initiatives underway. Finally, the conclusion examines the main current challenges facing cross-border economic integration in this sector and territory.

\section{THE TEXTILE AND CLOTHING SECTOR IN THE GALICIA-NORTH PORTUGAL TERRITORY}

The textile and clothing industry in North Portugal is mostly composed of small and mediumsized enterprises [13]. Those companies are strongly export-based and its competitiveness is founded in formal and informal intraregional networks of collaboration amongst themselves [2], which have greatly contributed to boosting this sector's regional dynamism. Its competitiveness also owes much to the high quality of the local production, resulting from the intergenerational transmission of accumulated tacit knowledge, coming from a long tradition in this line of business in North Portugal [10].

Despite the textile and clothing sector still remains one of the most representative in the business structure of North Portugal (in terms of employment and number of business establishments), from the mid-1990s the region suffered from a process of profound reconversion, which led to many companies closing and the loss of thousands of jobs $[1,8,16$, $21,24]$. This restructuring resulted in the bankruptcy of countless companies that were unable to maintain the competitive advantages on which their development had been based [25]. In other cases, the effect of the relocation of several foreign companies was also severe, as well as of national companies that decided to transfer their manufacturing (partially or totally) to countries with more competitive production costs. This reconversion process may have acted as a selection agent, gradually eliminating companies experiencing difficulties in adapting to the demands of global competition. However, it has also revealed companies in the North region that have been able to take advantage of this process to reinforce their competitive capacity, particularly through the public policies and financial instruments that have been devised to qualify the regional productive base [2]. These are, especially, companies that were able to recognize the need to invest in research and innovation, in increasing the use of technology in the production process, in reinforcing marketing and promotion actions, as well as in training and professional qualification. Consequently, they redirected their competitiveness from lower wage costs towards guaranteeing high quality production. At the same time, a few companies, in much lower number, turned to the creation of their own brands and to structuring retail networks, ensuring the more value-added segments of this economic 
value chain, not only production but especially upstream activities, such as design, or downstream activities after production, such as logistics and distribution [25].

On the other side of the border, Galicia is characterized by a business structure not so dense as in North Portugal's [10], in terms of number of companies and workers, and it did not suffer from the same degree of vulnerability with regard to the competitive pressures of globalization, precisely because it has developed a more balanced value chain $[3,15,23]$. These entrepreneurial agents recognized early the importance of investment in technology, the relevance of design and quality, the need to create their own brands, as well as the advantages of applying market research methodologies which provided them with prior information about the consumers' preferences [3]. It was, consequently, able to evolve from small textile manufacturing units to high turnover companies, which would in turn subcontract smaller local companies at certain stages in the manufacturing process. Although there are signs of strong relations of interdependency among Galician companies, which have bolstered the region's dynamism in this sector, this trend happened simultaneously with significant externalization of production to territories with lower wage costs, as it is the case of the North Portugal [7].

If the entrepreneurial fabric of North Portugal is generally characterized by small and mediumsized companies, Galicia has witnessed a process of capital concentration (via mergers and acquisitions), particularly by a large economic group, the Inditex Group, which is responsible for over 70\% of the sector's total sales turnover in Galicia, and for $45 \%$ of the joint sales turnover of the Galicia-North Portugal Euroregion [10]. This concentration of capital, despite the risks this may entail, gives this economic group considerable weight and negotiating power which greatly benefits the region's entrepreneurial structure, affording Galicia an enviable competitive advantage in the global competitive market of the textile and clothing industry. It should, however, be noted that, with the exception of the major companies, a large majority of Galicia's companies with their own brands generally distributes their products in the domestic market, whether through their own distribution or franchised channels or through multi-brand channels (independent stores or large retailers). This excessive dependence on internal demand and Spanish purchasing power comprises this sector's main frailty in Galicia, especially in periods of weaker economic performance in Spain.

These are, then, two neighboring regions with very distinct specialization profiles in the textile and clothing sector. According to the database of the EuroClusTex project (financed by POCTEP -Spain-Portugal Cross-border Cooperation Programme), at the beginning of the 2010s, there were over ten thousand companies in the textile and clothing industry in the Galicia-North Portugal Euroregion, with a very unequal geographical distribution. The districts of Braga and Porto (both in North Portugal) alone accounted for $85 \%$ of the sector's total companies in the Euroregion, whereas only $12 \%$ were located in Galicia. However, these Galician companies, located particularly in Coruna and Pontevedra, accounted for almost 2/3 (13.4 billion Euros) of the sector's total turnover in the Euroregion. This scenario very clearly highlights the distinct specialization profiles of these two border regions, resulting from very different entrepreneurial strategies and business models. Galicia, in comparison to North Portugal, is home to a larger number of trade companies (wholesale and retail) and it is precisely the activities associated to distribution in this sector which are responsible for the high turnover in Galicia. It is worth noting that trade activities are responsible for $86 \%$ of Galicia's sales turnover, whereas in North Portugal those activities accounts for only $23 \%$ as most of its turnover comes specially from product development activities. 
These are, thus, complementary profiles of specialization that, from a comprehensive perspective, would ensure a highly balanced value chain for this territory as a whole, underpinning a strong competitive advantage within the global panorama of the textile and clothing industry. But for this competitive advantage to occur, different links in the value chain need to be articulated on both sides of the border. This will require institutional alliances and cooperation networks among companies, by establishing agreements and joint business projects, as well as more complex initiatives, such as capital investment shares in companies or mergers and acquisitions. In the next two sections, it will be analyzed how the sharing of resources, abilities, competences and specializations between these two border regions have been able to promote the development of institutional and business cooperation initiatives.

\section{CROSS-BORDER INSTITUTIONAL COOPERATION}

With the purpose of stimulating institutional cooperation, the sector's most representative associations in the two border regions (ATP - Textile and Clothing Association of Portugal; CITEVE - Technological Institute for the Portuguese Textile and Clothing Industry; and AIPCLOP - Textile and Clothing Association of Lugo, Ourense e Pontevedra) submitted the EuroClustex Project (which began in 2009) and the EuroClustex+ Project (which began in 2012) to POCTEP (Spain-Portugal Cross-border Cooperation Programme). These projects, financed with European Commission funds, have operated as catalysts to the complementarities between the two regions, intended to consolidate a cross-border cluster by establishing contacts and cooperation between the main actors in the sector on both sides of the border. We now intend to identify the main signs of this clustering process, so as to determine the main contributions from the institutional interactions underway among the sector's major actors. There are clear signs of increased institutional interactions in this sector in this territory, related mainly to four types of institutional actors: the sector's most representative associations; technological innovation institutes; fashion events; and training institutes.

Annual meetings have been held since 2009 among the sector's most representative associations in the two regions (Portuguese-Galician Fashion Cluster Forum), to discuss common themes and challenges, as well as implement ideas that can in practice contribute to bolstering complementarity and the cross-border cluster. These meetings have acted as platforms for exchange and dialogue, fostering furthermore contacts between employers and unions on both sides of the border, bringing them closer and facilitating joint collaboration and work. They have also served to exchange experiences and encourage collective learning based on initiatives which have successfully or unsuccessfully taken place in each of the regions. They further provide the opportunity to evaluate the role of public administrations in bolstering the sector, as well as to publicize the cluster and its vitality.

In terms of cooperation among technological innovation institutes, CITEVE (Centro Tecnológico das Indústrias Têxtil e Vestuário de Portugal) and TEXTEC (Instituto Tecnológico de Innovación Têxtil da Galiza), have worked together to develop joint projects. Exchanges of information have taken place between these two technological and research centers, intended to foster collective efficiency, rationalize efforts and optimize resources. In this regard, it is noteworthy that CITEVE has opened a branch in Vigo (on the other side of the border), thus expanding the services it provides, namely support for the sector's technological development, to Galician companies.

With regard to cooperation in the Euroregion's major fashion events, particularly noteworthy are the agreements that have been established between PORTUGAL FASHION and Passarela 
PONTUS VETERIS, aimed at incorporating joint promotion initiatives that, for example, mean Portuguese designers have participated in Galicia's main fashion event and Galician designers have participated in Portugal's main event.

In terms of cooperation among training institutes, joint initiatives have taken place between Escola Superior de Diseño Goymar in Vigo and Modatex in Porto, which have allowed future professionals in the sector to become familiar with the reality of their neighboring region. Examples include student exchanges between the two institutes and visits by Vigo students to the sector's largest fair in Porto in the North Portugal (Modtissimo), where they were able to present their work and skills.

Additionally, three important measures supported by the sector's institutional agents were developed to foster greater cross-border interaction between companies from both sides of the border. First, the creation and permanent updating of an online database identifying the business agents in this value chain in Galicia and North Portugal, intended to facilitate joint business projects and greater cooperation among companies. Companies in this database can be searched for by location, activity or product. Second, an online platform is available to announce calls for cooperation with companies in the neighboring region, as well as to search for potential business partners. A search on this platform shows, for example, that several Galician companies are currently looking for companies in North Portugal for product development, whereas North Portuguese companies are looking for agents to sell their products in Spain. Finally, the establishment of CIMTEX (Iberian Center for Textile Mediation) intends to facilitate business relationships between the two regions, providing free services such as personalized support for brands and designers to identify the manufacturers that best suit their needs and conditions, or providing mediation in out-of-court dispute settlements that may arise in the course of cooperation.

\section{CROSS-BORDER BUSINESS COOPERATION}

In order to evaluate the business cooperation efforts between North Portugal and Galicia, indepth interviews were conducted with a sample of 65 companies headquartered in North Portugal. The sample reveals a high level of diversity, not only geographically (companies are located in 16 municipalities), but also in terms of the activities represented (textile companies, clothing companies and companies specialized in complementary activities, such as cutting, dyeing, embroidery, etc.). The diversity is also present in terms of size, both in number of workers (from micro companies with only 10 workers to large enterprises with over 250 workers), and turnover (from companies with an annual turnover lower than 100 thousand euros to companies with annual sales of over 5 million euros).

Three main trajectories for the companies in the region can be identified in the sample analyzed. First, several companies were established during the period of the Portuguese dictatorship and showed great resilience over the years, having maintained their competitiveness in moments of historical complexity: the transition to democracy in the 1970s; the crisis of the 1990s, strife with bankruptcies and mass layoffs, especially in textile production, while also suffering from competition from Eastern Europe; liberalization of the textile trade in 2005 with the entry of China into the World Trade Organization and the rise in international competition in the sector. Second, companies established in the 1980s and 1990s revealed a process of gradual transition, having often started in small outbuildings lacking adequate conditions, later moving to small, rented warehouses and then to industrial pavilions, generally furbished with better access routes. Today, many are quality certified companies able to comply with all requirements in terms of hygiene and work safety procedures. In this 
category, though, there is a wide range of situations, as some of the companies have not yet achieved the more advanced levels in this evolutionary process.

Lastly, companies established after 2000 are, roughly speaking, of two types. The first type includes recent companies that have emerged from a process of business recycling, resulting from highly dynamic business demographics in this region and this sector (high company death and birth rates). New companies can sometimes arise from a bankruptcy, founded by some of the more entrepreneuring unemployed workers who detain know-how in the sector. The second type includes company branches founded to support large companies. These can be national seeking to make part of their production more autonomous, or international companies that have decided to locate production segments of their value chain in this region.

Based on information gathered from the interviews, it is important to underline that the business interactions with Galicia are restricted exclusively to intense trade relations. Galicia is one of the major destinations for exports from North Portugal. These can be direct or indirect, through other companies located in North Portugal, with which some of the companies interviewed have subcontracting arrangements. Some cases of indirect exports also take place through companies located in other Spanish autonomous regions (for example, Catalonia or Madrid) which produce for Galician companies but subcontract manufacturing in North Portugal. These products are then expedited directly to Galicia, taking advantage of geographical proximity, which reduces transport costs and ensures rapid delivery of orders, currently one of the most relevant requirements for orders from Galician companies. Galician brands have their own distribution networks and firmly secure their position by actively participating in the launching of new trends. They thus value rapid production, ensuring they satisfy clients' wishes in real time. Rapid delivery of orders is consequently one of the most important dimensions of North Portugal's competitiveness with regard to competition from Asia or other markets, like Turkey or Morocco [13].

It is, thus, possible to say that the textile and clothing industry of North Portugal, traditionally integrated in rather vast production networks based on low-wage exporting activities [24], is currently also part of cross-border production networks, particularly since the Zara brand was established by the Inditex group. North Portugal's strong specialization in the textile industry has sustained the rapid growth of this Galician company, taking advantage particularly of wage differences, which are lower in North Portugal, as well as of the good road infrastructure connecting the two regions [12].

The Inditex Group clearly dominates North Portugal's exports to Galicia. This group accounts for a major portion of total sales to Galicia of almost all the companies interviewed, representing in some cases over $70 \%$ of their production. This prevalence brings greater negotiating power, responsible in many cases for narrowing the profit margins of North Portugal's companies. However, in order to overcome this situation, some of the companies interviewed have been making efforts to integrate higher value added segments in this production chain. A few companies have gone beyond the simple production of models whose design is provided by the Galician client, having invested in their own design departments. They have produced prototype collections from which clients select and order a few models that are, however, produced under the client's label. Investments by North Portuguese companies in their own brands and distribution networks are still very rare. When they exist, it is mostly a business strategy to complement subcontracting. In other words, advancing towards other segments of the value chain has proven a very slow process and has yet to have any significant repercussions on increasing North Portugal's added value. 
Consequently, despite institutional cross-border cooperation in this Euroregion, the sample analyzed reveals a lack of extra-commercial partnerships between entrepreneurs in Galicia and North Portugal. This denotes difficulties in upgrading the business networks across the border, which are still eminently shaped by rationales of subcontracting and mere business competition. Indeed, we were unable to identify more ambitious initiatives of business cooperation that seek to take advantage of local and complementary resources in each region, such as joint capital investment, company mergers, or business collaboration in joint projects, to launch new brands or create/expand trade networks. Although the companies interviewed value and base part of their competitiveness on business partnerships and joint projects, these cooperation networks are restricted to North Portugal and do not as yet extend to the other side of the border. North Portugal is a territory with a high level of business cooperation but of an intraregional nature, based on a capital of trust that has been structured over the years. These partnerships are often motivated by the need to gain size as a means to guarantee the ability to respond to orders from Galician companies.

\section{CONCLUSION}

In the last few years, cross-border cooperation initiatives have been developed with a view to explore complementarities and broaden economic relationships in the Galicia-North Portugal territory, so as to ultimately bolster its joint competitiveness in an increasingly more globalized and internationalized economy. This study intended to evaluate the degree of economic integration specifically in the textile/clothing industry, not only because it is a major sector of activity in the productive structure of both regions, but also because the sector is currently experiencing a process of profound restructuring to face progressive integration in global markets.

There are some signs of an ongoing cross-border clustering process in the textile and clothing sector in this territory, deriving especially from more intense institutional cooperation among the sector's main actors. However, the progressive consolidation of this cluster depends on a number of challenges, one of which related to the need for greater maturity in the business relationships between Galicia and North Portugal. These still seem to be shaped by some cultural barriers associated to the border effect, which has remained, although differently from the past. In fact, the interviews suggested there are cultural issues which have led Galician companies to opt for business partners in other Spanish autonomous communities. These are more distant than North Portugal and lack its culture of excellence in textile manufacture, recognized internationally not only in terms of production but also more recently for its processes of innovation and technological development.

Cross-border business interaction is rooted above all in accumulated commercial capital, which has taken advantage of a model of 'competitive cooperation', by boosting and synchronizing resources and more competitive practices on both sides of the border. There are, consequently, intense relations among the companies in the two regions, but the challenge now is the need to upgrade these relations by, for example, creating mixed capital or shared capital investment companies on both sides of the border, or through mergers, or simply by participation in joint business partnerships and projects.

The increase in capital flows between the two regions can help to overcome the effects of a strong polarization experienced by this sector in this territory. On the one hand, large successful companies, particularly Galician, that are well established in international markets and control the entire value chain. It is precisely because of this diversity and their dominant positioning in the markets that they are able to grow even in times of financial and economic crisis. At the other extreme, there are many strongly specialized small and medium-sized 
companies that tend to perform in the market independently, thus experiencing the effects of financial and economic crises more severely. One of the main challenges here is the need to reinvent the relationships among these smaller companies (manufacturers and distribution brands/companies), looking for ways for integration that not only raise their competitive capacity in international markets but also give them the ability to respond more efficiently to the rapid changes in the sector. Indeed, the consolidation of this cluster may give the companies a critical dimension they currently lack, which is critical to their competitiveness. It is clear that the large companies in this sector have greater negotiating power and can undoubtedly sell and buy better than their competitors.

This challenge also arises from the fact that several Galician companies depend exclusively on the Spanish market. There is an urgent need that they expand their activities to external markets, however they are unable to do so independently due to lack of size. This could be an opportunity to increase cooperation with companies in North Portugal, not only through subcontracting but also through joint business projects, especially with those companies that already have long-standing, consolidated internationalization due to the insufficient Portuguese domestic market.

The ongoing process of cross-border clustering in this territory is a slow one that faces several challenges in the near future, associated not only to an incipient culture of cooperation among economic actors on both sides of the border (apart from the relations of subcontracting based on simple trade exchanges), but also because cooperation between the main institutional actors is still quite recent. To achieve greater levels of maturity in these cross-border interactions will take time and leadership. The sustainability of this leadership depends on continuing public support which has served to motivate and bolster these dynamics of institutional and business cooperation.

\section{References}

Amador, J. and Opromolla, L., Os sectores exportadores de têxteis e vestuário em Portugal, Boletim Económico: Artigos - Banco de Portugal, 2009, pp. 55-178.

Bessa, D. and Vaz, P., Contributo para um Plano Estratégico para a Indústria Têxtil e do Vestuário Portuguesa, Vila Nova de Famalicão: ATP - Associação Têxtil e Vestuário de Portugal, 2007.

Bonnin, A., The fashion industry in Galicia: understanding the'Zara'phenomenon, European Planning Studies, 10(4), 2002, pp. 519-527.

Burger, P., Džupka, P., Hudec, O., Suhányi, L., and Urbančíková, N., Preconditions of successful cross-border cluster in renewable energy sources, in 1st Knowbridge Conference on Renewables, Miskolc, 2010, 8p.

Guercini,S.; Becagli, C. and Ranfagni, S., Conviviality and its impact on business relationships: insights into an entrepreneurial textile-clothing community, Journal of Global Fashion Marketing, 8(3), 2017, pp. $235-249$.

Lange, E. and Nunes, F., Coopetição' transfronteiriça Galiza-Norte de Portugal: da cooperação institucional à cooperação empresarial, in Correia, T.; Henriques, V. an Julião, R. (Orgs.), Actas do IX Congresso da Geografia Portuguesa. Geografia: espaço, natureza, sociedade e ciência, Lisboa: Associação Portuguesa de Geógrafos, 2013, pp. 597-602.

Leal, A., A atitude dos jovens portugueses face às marcas de vestuário portuguesas e galegas, Porto: Universidade Fernando Pessoa, 2006.

Melo, M. and Duarte, T., Têxtil e Vestuário: deslocalização ou relocalização, Lisboa: Gabinete de Estudos e Prospectiva Económica do Ministério da Economia, 2001.

Mikhaylov, S., Features of the triple helix model in cross-border clusters, World Applied Science Journal, 21(12), 2013, pp. 1734-1738.

Nunes, F., O cluster transfronteiriço têxtil/vestuário/moda na Euroregião Galiza/Norte de Portugal, Revista Portuguesa de Estudos Regionais, № 27, 2011, pp. 41-48 
Nunes, F., Cooperação Empresarial Transfronteiriça na Euroregião Galiza-Norte de Portugal: o sector do têxtil e vestuário, in Royé, D. et al. (Coord.), Actas do XIII Colóquio Ibérico de Geografia. Respuestas de la Geografía Ibérica a la crisis actual, Santiago de Compostela: Meubook, 2012, pp. 1300-1309.

Nunes, F. and Pires, I., O tecido empresarial português promotor do processo de integração económica na Euroregião Galiza-Norte de Portugal, in Actas do XII Colóquio Ibérico de Geografia - 6 a 9 de Outubro de 2010, Porto: Faculdade de Letras da Universidade do Porto, 2010, 20 p.

Nunes, F. and Pires, I., 0 cluster do têxtil/vestuário na Euroregião Galiza - Norte de Portugal: um ambicioso desafio de cooperação económica transfronteiriça, in Actas do 17을 Congresso da APDR. Gestão de Bens Comuns e Desenvolvimento Regional Sustentável, Angra do Heroísmo: APDR - Associação Portuguesa de Desenvolvimento Regional, 2011, pp. 1034-1054.

Oliveira, E., Constructing regional advantage in branding the cross-border Euroregion Galicia-northern Portugal, Regional Science, 2(1), 2015, pp. 341-349.

Orcao, A. and Pérez, D., Global production chains in the fast fashion sector, transports and logistics: the case of the Spanish retailer Inditex, Investigaciones Geográficas, Boletín del Instituto de Geografía, 2014(85), 2014, pp. 113127.

Ramos, A., O Movimento de internacionalização empresarial na indústria do vestuário-o caso Português, Gestão e Desenvolvimento, 12, 2004, pp. 47-79.

Ravenhill, J., Global political economy, Oxford: Oxford University Press, 2017.

Royer, S., Crossing - borders: International clusters. An analysis of Medicon Valley based on value-adding web, Flensburg: Flensburg University Press, 2007.

Simmons, B.; Dobbin, F. and Garrett, G. (Eds.), The global diffusion of markets and democracy, Cambridge: Cambridge University Press, 2008.

Simmons, B. and Elkins, Z., The globalization of liberalization: Policy diffusion in the international political economy, American Political Science Review, 98(1), 2004, pp. 171-189.

Soares, E., A entrada da China na OMC: ameaça ou oportunidade: o caso da indústria têxtil e de vestuário no norte de Portugal, Braga: Universidade do Minho, 2012.

Sohn, A.; Vieira, F.; Filho, N.; Cunha, I. and Zarelli, P., Knowledge Transmission in Industrial Clusters: Evidence from EuroClusTex, European Planning Studies, 24(3), 2016, pp. 511-529.

Tokatli, N., Global sourcing: insights from the global clothing industry—-the case of Zara, a fast fashion retailer, Journal of Economic Geography, 8(1), 2008, pp. 21-38.

Thiel, J.; Pires, I. and Dudleston, A., Globalisation and the Portuguese Textile and Clothing Filière in the Post GATT Climate, In Guinta, A.; Lagendijk, A, and Piken, A. (Ed.), Restructuring Industry and Territory: The Experience of Europe's Regions, London: The Stationary Office, 2000, pp. 109-124.

Vasconcelos, E., Análise da indústria têxtil e do vestuário, Braga: EditValue, 2006.

Zámborský P., Emergence of Transnational Clusters, Journal for East European Management Studies, 16(4), 2012, pp. 464-479. 